\title{
SYNOPTIC CHARACTERISTICS OF AN EXTREME WEATHER EVENT: THE TORNADIC WATERSPOUT IN TIVAT (MONTENEGRO), ON JUNE 9, 2018
}

\section{Jovan Mihajlović1 (D) Dragan Burić ${ }^{2}$ (ID $・$ Vladan Ducić ${ }^{1}$ - Milan Milenković ${ }^{3}$}

\author{
${ }^{1}$ Faculty of Geography \\ University of Belgrade \\ Studentski trg 3/3, 11000 Belgrade: Serbia \\ e-mails: millennijum@hotmail.com • vladanducic@yahoo.com \\ ${ }^{2}$ Faculty of Philosophy, Department of Geography \\ University of Montenegro \\ Danila Bojovica bb, 81400 Nikšić: Montenegro \\ e-mail: dragan.buric@meteo.co.me (corresponding author) \\ ${ }^{3}$ Geographical Institute "Jovan Cvijić" \\ Serbian Academy of Sciences and Arts \\ Djure Jakšića 9, 11000 Belgrade: Serbia \\ e-mail: milenkovic011@gmail.com
}

\begin{abstract}
Recently Montenegro has often been faced with extreme weather events. The aim of this paper is to provide a detailed synoptic analysis of a severe weather event, a waterspout, and to confirm an indication that in most cases such events could potentially be forecasted, which is of great practical significance, since human lives and property can be saved. The paper presents the research results of synoptic and mesoscale weather conditions which created a favourable meteorological environment for a waterspout development in Tivat (Montenegrin coast) on June 9, 2018, around 01 UTC (03 CET). Based on field survey analysis, the rating of tornado intensity by the Fujita scale ( $F$-scale) has been done by assessing the damage. The synoptic type for this situation was CLOSED-SW and was determined by a detailed examination of atmospheric circulation. The results presented in the manuscript can help decision makers in Montenegro to take certain adaptation measures (above all, in tourism and construction) in order to mitigate the negative consequences of weather extremes.
\end{abstract}

\section{Key words}

extreme weather $\bullet$ waterspout $・$ synoptic conditions $・$ Tivat $・$ Adriatic Sea $・$ Montenegro 


\section{Introduction}

Although waterspouts are most common in the southeastern United States (Florida Keys) and parts of the Mexican Gulf (Rossow, 1970; Golden, 1977), these extreme local storms are a global phenomenon (Snow, 2020), and were also registered in various parts of the Mediterranean, most often in the summer and autumn seasons (Sioutas \& Keul, 2007). The process of formation of this extreme weather phenomenon, as well as its duration and spatial coverage, has been described in many papers (e.g. Huschke, 1959; Browning, 1964; Golden, 1974; Brady \& Szoke, 1988; Hagemeyer, 1994; DaviesJones et. al., 2001; Mihajlović et al., 2016).

Considering the waterspout climatology in Europe, Dotzek (2001; 2003) suggests that 160 waterspouts on the average are recorded in Europe annually. There are research papers dealing with the waterspout climatology in the Mediterranean region (Peterson, 1998; Penzar et al., 2001; Holzer, 2001; Sioutas \& Flocas, 2003; Gianfreda et al., 2005; Bissolli et al., 2007; Sioutas, 2011; Zanini et al., 2017; Pipinato, 2018). However, Sioutas and Keul (2007) emphasize the fact that there is no established waterspout climatology in the Mediterranean region, partly because of the limited literature dealing with the topic, particularly in the Eastern Mediterranean.

Sioutas and Keul (2007) observed 28 cases in total in the Adratic, lonian and Aegean Sea from July to November in 2002. Of a total of 28 observed cases, 13 waterspouts belonged to fair weather waterspouts, while 15 were tornadic events. The largest number of tornadic events (7) was actually recorded in the Adriatic Sea in the early morning hours (from 06-08 UTC), that is, tornadic waterspout activity was most prominent during these time intervals. The same authors (Sioutas \& Keul, 2007) determined synoptic types and mesoscale environment (by using different instability indices) which cause waterspout development. Based on their research work, it is estimated that there is a yearly average of 16 waterspouts over the Adriatic Sea.

However, Renko et al. (2016) pointed out that waterspouts had been more often recorded over the Eastern Adriatic coast during the last decade. According to their research work, 359 waterspouts in 150 days were recorded in the period 2001-2013 over the Eastern Adriatic coast (a waterspout day is a day with at least one recorded waterspout). After the year 2005, there were 20 recorded waterspouts per year, and the maximum number was recorded exactly at the end of the observed period. 104 waterspouts were recorded in 2013, most of them in the vicinity of Dubrovnik (39 waterspouts). Dubrovnik is a city located in Croatia, relatively close to Tivat, about $50 \mathrm{~km}$ away. The highest number of waterspouts has been recorded in summer months, particularly during August. Nevertheless, the authors point out that the increase in waterspout frequency cannot be exclusively explained by the change of meteorological environment, but also by the fact that the public interest in weather phenomena has increased, too. Also, the internet helps information spread faster than ever.

Over the last few decades, the Mediterranean, including the Western Balkans region, has been experiencing more frequent weather extremes, such as extreme temperatures, heat waves, droughts and extreme precipitation (Spinoni et al., 2014; Stadtherr et al., 2016; Stagge et al., 2017; Kurnik et al., 2017; Mostafa et al., 2019). In the era of current climate change, that is, higher frequency of extreme weather events (IPCC, 2014), an early warning weather alert for the potential of severe weather is of great significance (WMO, 2016; Radović \& Iglesias, 2020). Therefore, the research work in this paper may represent a good example of a timely warning weather alert for extreme weather events, which has a great practical significance. The function of an early warning weather alert for the potential of severe weather events is to save human lives and to mitigate the property damage. 
Montenegro doesn't have a developed system for waterspout detection or monitoring of other air vortices. The only way to record such weather events is when a meteorological technician at a weather station reports that a waterspout or a landspout has occurred, or when local people, tourists or print and electronic media deliver the information of such an event on the internet. As it is said, a waterspout is not something unusual for the Eastern Adriatic coast, that is, for the Montenegro coast, but being exclusively local in nature, many waterspouts occur unnoticed. Print and electronic media, as well as some individuals have recorded a few waterspout events along the Montenegro coast (Tab. 1), but such information cannot be confirmed by the national Institute of Hydrometeorology and Seismology of Montenegro (IHMSM) since the Institute doesn't have the events recorded in its database. Therefore, the waterspout event on June 9, 2018 in Tivat has been analysed for three reasons:

1. there was an information issued by an official national institution (IHMSM), that is, the weather station at the Tivat airport, which confirmed the waterspout event that caused a real chaos on its narrow path;

2. these events have been more often recorded during the last 10 years;

3. a waterspout of such intensity has not been recorded on the Montenegro coast so far.
Considering current climate change, it is quite likely that such events are going to occur more often so it is necessary to pay more attention to waterspouts and to other extreme weather events.

Therefore, the research objective of this paper is a detailed synoptic analysis of a severe weather event, the waterspout recorded in Tivat (the coordinates: $42.40^{\circ} \mathrm{N}$, $18.73^{\circ} \mathrm{E}$, elevation $5.4 \mathrm{~m}$ ) on June 9, 2018, which swept over the town in the early morning hours (around 03:00 CET, that is, 01:00 UTC). An extreme rainfall, strong wind gusts and thunderstorm processes were recorded locally in a short time period. This extreme weather event caused significant property damage, but fortunately no human losses. In order to emphasize the fact that extreme weather events can be potentially forecasted, numerical model outputs, which were obtained one or two days before the waterspout event, have been analysed. It is important to point out that the waterspout had been forecasted two days before it actually occurred. Therefore, this paper has another objective: to suggest the fact that such events can be timely forecasted with high probability by analysing various synoptic tools. It is of practical significance since that way human lives and property could be saved.

Table 1. Examples of recorded waterspouts on the Montenegrin coast

\begin{tabular}{|c|c|c|}
\hline Location & $\begin{array}{l}\text { Published } \\
\text { online }\end{array}$ & Source \\
\hline Budva & August, 8, 2010 & https://www.youtube.com/watch?v=038ZklqRfBM \\
\hline Ulcinj & August, 28, 2013 & https://www.youtube.com/watch?v=C0cO7SW4Vc4 \\
\hline Budva & September, 19, 2016 & $\begin{array}{l}\text { https://www.cdm.me/drustvo/video-i-foto-cudo-prirode-vise-pijavica- } \\
\text { na-crnogorskom-primorju/ }\end{array}$ \\
\hline Bar & September, 9, 2017 & $\begin{array}{l}\text { https://www.blic.rs/vesti/svet/vreme-divlja-i-na-jadranu-mali-tornado- } \\
\text { u-crnoj-gori-foto/xbtwp0x }\end{array}$ \\
\hline Herceg Novi & February, 18, 2017 & $\begin{array}{l}\text { http://www.rtcg.me/vijesti/drustvo/156872/dvije-pijavice-na-ulazu-u- } \\
\text { boku.html }\end{array}$ \\
\hline Budva and Bar & January, 14, 2018 & https://www.youtube.com/watch?v=F4cO_8j_bwk \\
\hline Ulcinj & November, 11, 2019 & $\begin{array}{l}\text { https://www.antenam.net/drustvo/139281-pogledajte-pijavica-na- } \\
\text { moru-kod-ulcinja }\end{array}$ \\
\hline
\end{tabular}




\section{Study area, data and methodology}

\section{Study area}

The study includes the southwest part of Montenegro, that is, the Bay of Kotor and the town of Tivat in which the waterspout was recorded in the early morning hours on June 9, 2018. Montenegro has a very heterogeneous relief and the configuration and orography of the Bay of Kotor are very complex. In geomorphological terms, the Bay of Kotor is a unique entity of the Adriatic Sea. The bay is surrounded by slopes of mountains whose peaks rise above 1500 m (Orjen, 1894 m; Lovćen, $1749 \mathrm{~m}$ ) and has a specific shape with two narrows and two extensions (Fig. 1). The shape of the bay has quite a strong impact on wind speed and direction. Specifically, the southern winds are getting stronger in the Bay since the currents are tight. In the southern currents, the air forcibly rises along the slopes of the mountains, that is, it is cooling, which causes the condensation of water vapor, the formation of frequent thunderstorm clouds, and the precipitation of typical orographic type. The north and northeast wind (bora) in winter cools the air in the Bay, while in summer it can raise its temperature. Due to the

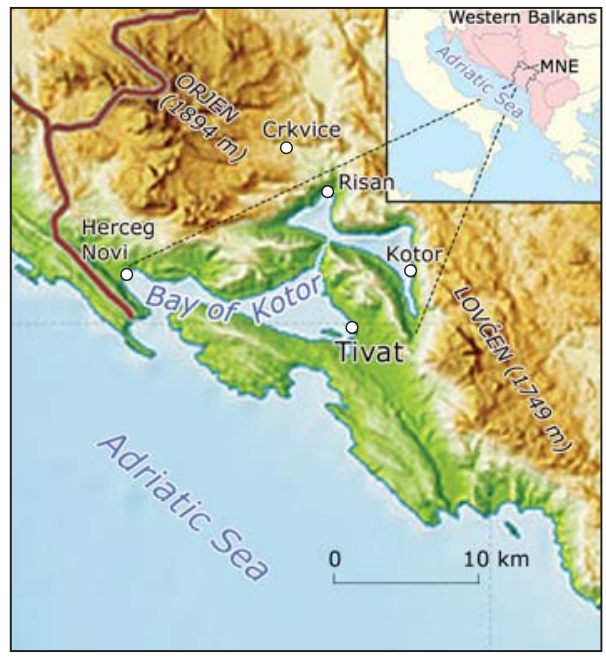

Figure 1. Location of the Bay of Kotor in Montenegro (MNE) and the Western Balkans configuration of the terrain, stronger winds in the Bay often form eddy currents.

The Bay of Kotor is one of the most beautiful bays in the Mediterranean. It looks like Scandinavian fjords, but it is tectonically predisposed and morphologically formed by exogenous forces (karst, fluvial, and other erosion processes). The whole of the southwest part of Montenegro is formed by limestone of great compactness. The Bay of Kotor stretches inland for about $28 \mathrm{~km}$. The Bay of Kotor lies within the Mediterranean climate (according to Köppen climate classification Csa type) which is modified in the hinterland on mountain slopes as altitude increases. In the immediate hinterland of the Bay of Kotor is Mount Orjen, on whose slopes lies the site of Crkvice, known for its heavy rainfall. The average annual rainfall in Crkvice is about $4600 \mathrm{~mm}$ - it is probably the wettest place in Europe. Such a large amount of precipitation is undoubtedly due to the position of Crkvice in relation to the dominant moist air masses from the south (Burić et al., 2013; 2014). This extreme rainfall is related to certain types of atmospheric circulation, shown by the "SynopVisGrosswetterlagen" (SVG) series, which is a part of the Hess and Brezowsky Grosswetterlagen (GWL) system (Ducić et al., 2012).

\section{Data and methodology}

During the research and while analysing meteorological conditions, which caused the waterspout event in Tivat, the data about the surface and upper level structure of the atmosphere (absolute topography (AT) maps $500 \mathrm{hPa}$ / wind on $300 \mathrm{hPa}$ ), composite synoptic diagrams of various instability parameters (ML CAPE, LI, Soaring index, SRH), as well as diagrams of relative vorticity and relative vorticity advection on $500 \mathrm{hPa}$ were used. Sounding measurements and wind hodograph in the form of emagram (in resolution of $0.5 \mathrm{~km}$ ) were obtained on the basis of operational WRF-NMM model (Janjic et al., 2001; Janjic, 2003; Skamarock et al., 2008; Powers et al., 2017), which uses the 
data of the global model for medium-range weather forecast from Reading as input parameters (ECMWF). Cloudiness, which caused the waterspout occurrence in Tivat, was observed by meteorological radar MRL-5 of dual wavelength $\left(\lambda_{1}=3.2 \mathrm{~cm}\right.$, $\lambda_{2}=10 \mathrm{~cm}$ ), in the radar centre in KosutnjakBelgrade. The most important details of this cloudiness, made in the ASU-MRL 2012 software for the time periods from 00:27 and 00:31 UTC (Fig. 8) are: composite image maximum reflectivity map (ZMAX) $(3-10 \mathrm{~cm})$ and severe weather events map $(3.2 \mathrm{~cm})$. Tools were used in order to determine vertical cross-section of selected convective cell in any direction (XSECT).

The data about sea surface temperatures (SST) and temperature anomaly of the Adriatic Sea on June 9, 2018 were obtained on the basis of POM (Princeton Ocean Model, that is, AREG: Adriatic Regional model) ocean model which is used by the Adriatic Forecasting System (AFS) (operational from April 2003), and which is developed and maintained by the Italian Group of Operational Oceanography (GNOO) (Oddo et al., 2005; 2006, Guarnieri et al., 2008). The ocean model includes the whole of the Adriatic basin with a horizontal resolution grid of $1 / 45^{\circ}$ (about $2.2 \mathrm{~km}$ ), on $31 \sigma$-layers. The topography of the basin bottom was made on the basis of U.S. Navy $1 / 60^{\circ}$ bathymetric database DBDB1, by bilinear interpolation of depth into the grid model. Various products of satellite images from geostationary satellite METEOSAT were also used.

Since waterspouts belong to remarkable and dangerous meteorological phenomena,

Table 2. Material used in the analysis of the waterspout event in Tivat (Montenegro)

\begin{tabular}{|c|c|c|}
\hline $\begin{array}{l}\text { Used parameters and } \\
\text { units of measurement }\end{array}$ & Equation & Source \\
\hline CAPE $\left[\mathrm{Jkg}^{-1}\right]$ & $C A P E=\int_{L F C}^{E}\left(\alpha_{i p}-\alpha\right) d p$ & $\begin{array}{l}\text { Moncrieff \& Miller (1976); } \\
\text { Glickman (2000) }\end{array}$ \\
\hline$L /\left[{ }^{\circ} \mathrm{C}\right]$ & $L I=T_{10}-T 500$ & Galway (1956) \\
\hline$K O$ index $\left[{ }^{\circ} \mathrm{C}\right]$ & $K O=1 / 2\left(\theta_{\ddot{A} 500}+\theta_{\ddot{A} 700}\right)-1 / 2\left(\theta_{\ddot{A} 850}+\theta_{\ddot{A} 1000}\right)$ & Kunz (2007) \\
\hline Soaring index $[\mathrm{K}]$ & $S O I=T 850-T 500+D 500-D 700$ & http://www1.wetter3.de/soaring_index.html \\
\hline TT index $\left[{ }^{\circ} \mathrm{C}\right]$ & $T T=(T 850-T 500)+(T d 850-T 500)$ & Miller (1967) \\
\hline$E H I$ & $E H I=\left(C A P E^{\star} S R H\right) / 160,000$ & Davies (1993) \\
\hline $\begin{array}{l}\operatorname{SREH}(0-1 \mathrm{~km} ; 0-3 \mathrm{~km}) \\
{\left[\mathrm{m}^{2} \mathrm{~s}^{-1}\right]}\end{array}$ & $S R H=\int_{0}(v-c) \cdot \omega d z$ & $\begin{array}{l}\text { Davies-Jones (1984) } \\
\text { Davies-Jones et al. (2001) }\end{array}$ \\
\hline Radar data & - & http://www.hidmet.gov.rs \\
\hline Satellite data & - & $\begin{array}{l}\text { http://www.eumetrain.org and https://www.eumet- } \\
\text { sat.int/website/home/index.html }\end{array}$ \\
\hline Model POM & - & $\begin{array}{l}\text { Oddo et al. }(2005,2006) \text {; Guarnieri et al. (2008) } \\
\text { http://oceanlab.cmcc.it/afs (Downloads: Decem- } \\
\text { ber, 2018) }\end{array}$ \\
\hline $\begin{array}{l}\text { Emagram and wind } \\
\text { hodograph }\end{array}$ & - & http://www.meteo.co.me/ \\
\hline Fujita Scale & - & $\begin{array}{l}\text { Fujita (1981) } \\
\text { (https://www.spc.noaa.gov/faq/tornado/f-scale.html }\end{array}$ \\
\hline $\begin{array}{l}\text { SYNOP data and other } \\
\text { prognostic and analyti- } \\
\text { cal material }\end{array}$ & - & $\begin{array}{l}\text { http://www.meteo.co.me/ } \\
\text { http://www.hidmet.gov.rs }\end{array}$ \\
\hline
\end{tabular}


that is, atmospheric hazards, we have applied the research methodology used in Florida (USA) (Rossow, 1970; Golden, 1977; Wakimoto \& Lew, 1993), and also in different parts of the Mediterranean (Sioutas \& Flocas, 2003; Sioutas \& Keul, 2007; Sioutas, 2011; Matsangouras et al., 2017). We have used the method of synoptic analysis in the research: surface temperature analysis (SST) of the Adriatic Sea based on the AREG ocean model, synoptic types analysis, radiosounding analysis and wind hodograph analysis, atmospheric stability analysis, analysis of various thermodynamic instability parameters, and wind parameter analysis, satellite and radar images analysis, and the Fujita Scale (Tab. 2).

The synoptic material for this research has been mainly obtained from the national Institute of Hydrometeorology and Seismology of Montenegro (IHMSM) and the Republic Hydrometeorological Service of Serbia (RHMSS). Both IHMSM and RHMSS use the WRF-NMM regional numerical model in weather forecasting. SYNOP data from meteorological stations in Montenegro, obtained from IHMSM, have also been used.

\section{Results}

\section{Analysis of global forecast models}

Two days before the waterspout event, the outputs of global forecast models indicated a possibility of an extreme weather event during the night of 8 and 9 June, 2018. The day after, a new initialization of forecasting models confirmed a strong atmospheric instability and, therefore, increased probability of a waterspout formation.

The structure of the upper-level atmosphere is shown by absolute topography maps (AT). On the AT $500 \mathrm{hPa}$ topography maps at 00 UTC and 06 UTC on June 9, 2018 (Fig. 2, A and B) a deep upper-level depression was observed in the northeast of Europe along with a low surface pressure. Low values of geopotential heights within the trough of an upper-level cyclone indicate extremely cold air (about $-30^{\circ} \mathrm{C}$ ). Above Scotland and northwest of Spain, the centres of secondary cyclones, with the trough extending along the Atlantic facade of Europe, were noticed - the so-called cut-off low closed by isotherm of $-20^{\circ} \mathrm{C}$. There was an inflow of warm air from the northwest of Africa moving over the southwest and south of Europe, and over the central parts up to the south of Scandinavia. All of this was happening within an upper-air southwest flow.

Synoptic material analysis from 00 UTC and 06 UTC indicates that the shallow surface cyclone, with the centre above the mid-Adriatic, moved slowly over the Balkan Peninsula during the night of June 8-9, 2018. In the same period, an axis of instability trough over the Adriatic was noticed at the AT $500 \mathrm{hPa}$ map. The area of Montenegro was in the front part of both of these baric features, that is, under the influence of the moist and instable south-southwestern flow. In the centre of the depression the temperature at AT $500 \mathrm{mb}$ was around $-15^{\circ} \mathrm{C}$, at AT $850 \mathrm{mb}$ around $10^{\circ} \mathrm{C}$, and at the surface around $25^{\circ} \mathrm{C}$, which indicates a pronounced vertical thermal gradient.

On the AT $700 \mathrm{hPa}$ map (Fig. 2C), an area of extreme relative air humidity can be observed in the whole of the Adriatic basin and, particularly, in the west Balkans, that is, the Bay of Kotor-around 90-95\%. On the AT $300 \mathrm{hPa}$ (Fig. 2D) a streak of jet stream (socalled jet streak) is noticed above the research area (the Bay of Kotor), with winds reaching the speed of around $90 \mathrm{kn}$ in the axis itself, that is, above the cyclonic field and frontal zone at the surface. A horizontal field of positive divergence is pronounced, supplying itself with kinetic energy from the jet streak. This field of positive divergence at $300 \mathrm{hPa}$ causes air convergence at the surface, which makes ideal conditions for a waterspout to develop.

Strong whirlwinds, such as waterspouts and landspouts, are very likely to be formed in specific meteorological conditions. These are local events, and it should be emphasized that they cannot be forecasted with great probability based on the analysis of global numerical models. In order to forecast extreme weather events (thunderstorm 

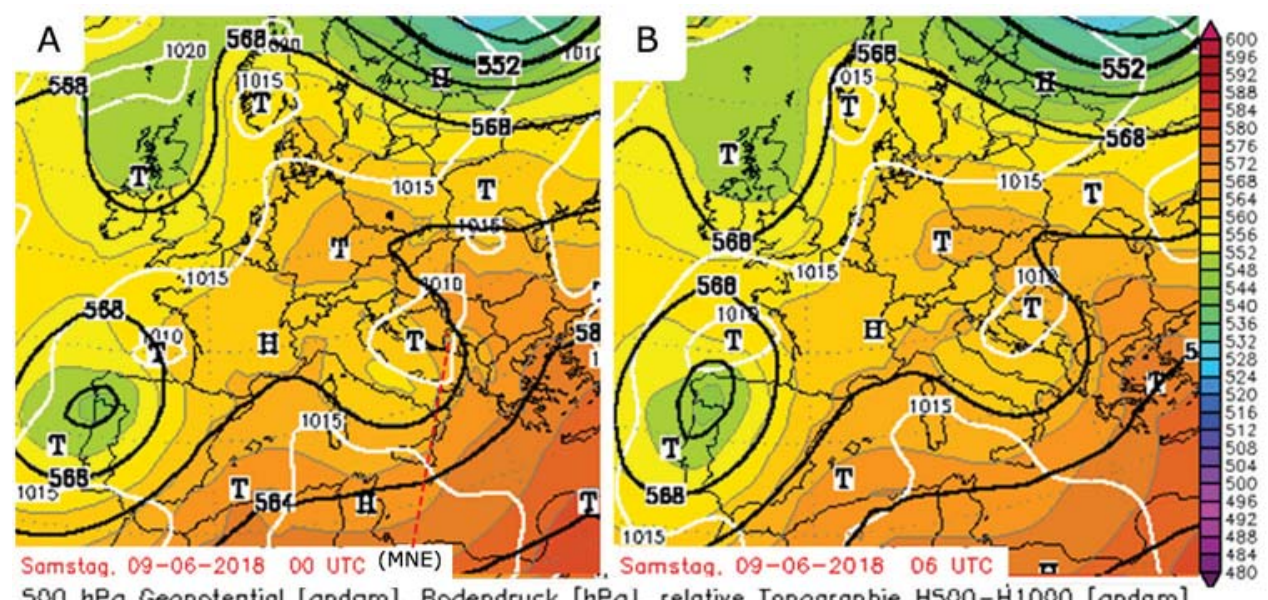

$500 \mathrm{hPo}$ Geopotential [gpdam]. Bodendruck [hPo], relative Topographie H500-H1000 [gpdam]
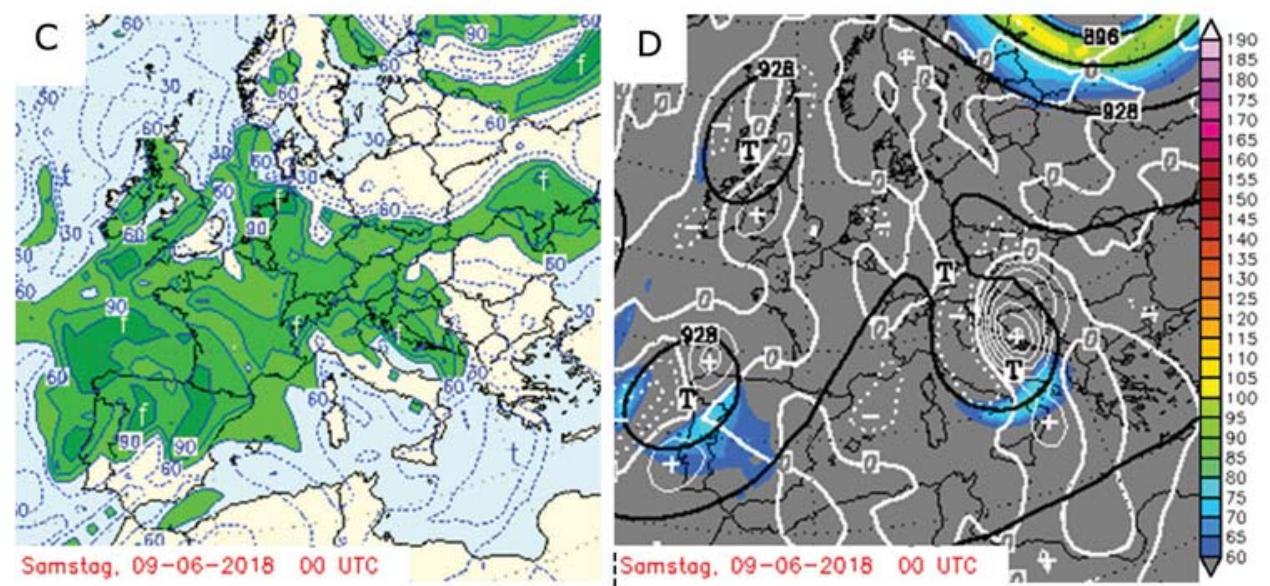

$700 \mathrm{hPo}$ relative Feuchte [\%] Isolinien bei 15 .

30, 45. 60. 75. $90 \%$

Extrema: $t<15 \%, f>95 \%$

$300 \mathrm{hPa}$ Wind [kn], horizontale Divergenz in Einheiten von $10 E-6 / s$, Geopotential [gpdam]

Figure 2. Geopotential and temperature at $500 \mathrm{hPa}$ at $00 \mathrm{UTC}(\mathrm{A})$ at $06 \mathrm{UTC}$ (B), relative humidity at $700 \mathrm{hPa}(\mathrm{C})$ and wind, horizontal divergence and geopotential at $300 \mathrm{hPa}(\mathrm{D})$ over Europe at 00 UTC, June 9, 2018

Source: Based on data from http://www1.wetter3.de/Archiv/

processes, storm winds, heavy rainfall, waterspouts, etc.) atmospheric instability indices have been used in the following analysis.

\section{Atmospheric instability indices}

In order to have a better insight into mesoscale processes which preceded and led to the waterspout formation in the
Bay of Kotor (Tivat), key instability indices and wind parameters forecasted by NCEP GFS model have been analysed for synoptic period 00 UTC (Fig. 3). The waterspout was formed between 00-01 UTC, but the GFS model parameters are available only in main synoptic periods. Therefore, the 00 UTC period will be considered as credible and the results as convincing. The focus of the analysis 


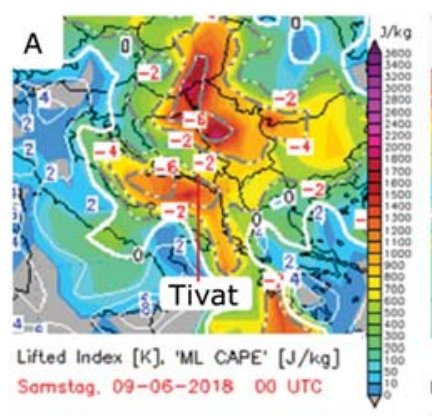

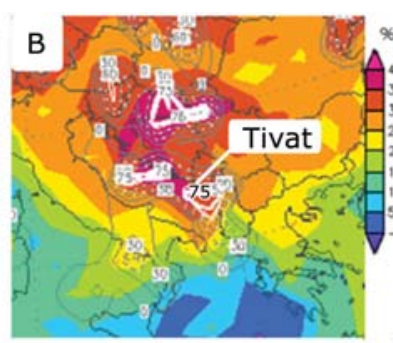

Soaring-Index $[\mathrm{K}]$. Hochreichende Konvektionsbewoelkung [ $[\pi]$ isolinien: 0 15 $304560657075 \pi$

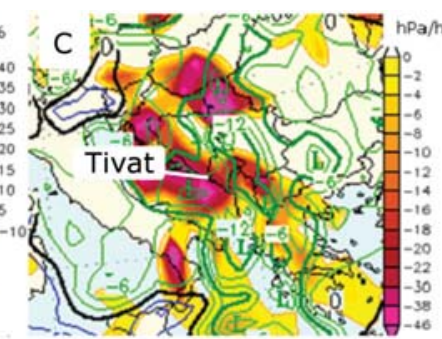

KO-Index $[K]$ (Isolinien) Extrema: $L<-6, S\rangle+6$. $500 \mathrm{hPa}$ Vertikalbewegung $[\mathrm{hPa} / \mathrm{h}]$ (Forbskala)

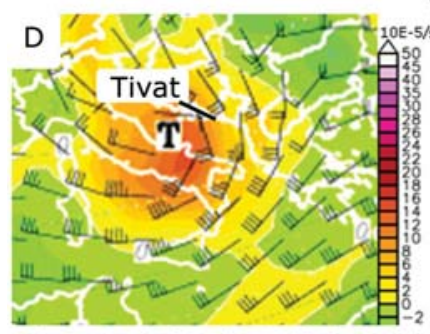

$500 \mathrm{hPo}$ Wind [kn], Relative Vorticity [10E-5/s]

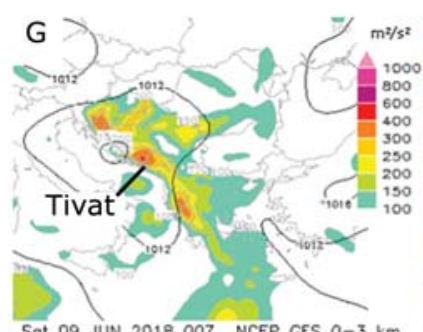

Sot 09 JUN 2018002 NCEP GFS $0-3 \mathrm{~km}$ storm-relative helicity using Bunkers Storm motion Mean sea level pressure in hPo (contours)

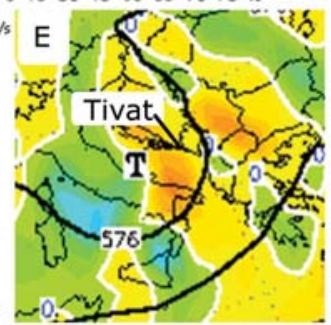

$500 \mathrm{hPo}$ Geopotentiol [gpdam]

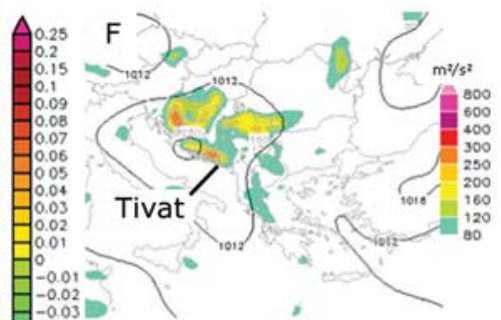

Advektion obsoluter Vorticity $[1 /(h+h)]$

Sot 09 JUN $201800 Z$ NCEP GFS $0-1 \mathrm{~km}$ storm-relative helicity using Bunkers Storm motion

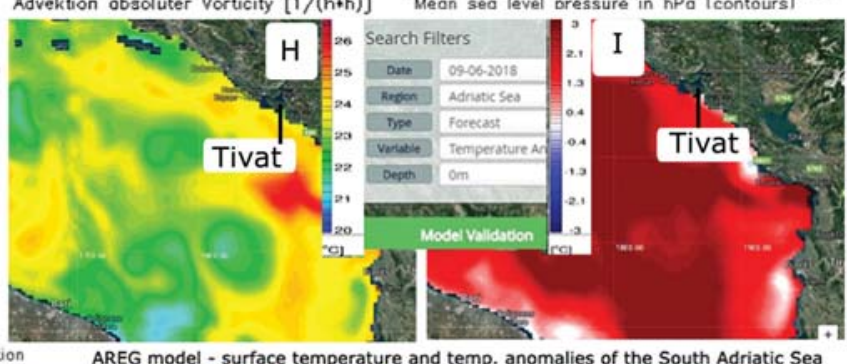

AREG model - surface temperature and temp. anomalies of the South Adriatic Sea

Figure 3. The forecast parameters at 00 UTC, June 9, 2018: (A) LI and ML CAPE, (B) Soaring index and convective clouds, (C) $\mathrm{KO}$ index and vertical motion, (D) relative vorticity and wind at $500 \mathrm{hPa}$, (E) advection of absolute vorticity at $500 \mathrm{hPa},(\mathrm{F})(0-1 \mathrm{~km}) \mathrm{SREH}$ (shaded) and the sea level pressure in hPA (contures), (G) (0-3 km) SREH (shaded) and the sea level pressure in hPA (contures), (H) surface temperature of the Adriatic Sea according to AREG model and (I) the temperature anomaly according to AREG model

Source: Based on data from http://www1.wetter3.de/Archiv/ and http://oceanlab.cmcc.it/afs/

is on the genesis, development and impact area of the waterspout.

The value of the of ML CAPE index (Mixed Layer Convective Available Potential Energy) was high over the whole area of the Balkans, and the strongest convective instability was present along the Montenegro coastline and on the west and northwest of Serbia - around $2000 \mathrm{~J} / \mathrm{kg}$, which means a rapid vertical storm development with a strong updraft. They also indicate a possibility of a large number of lightning strikes. Estimated value of $\mathrm{LI}$ (Lifted index) within the research area ranged from -2 to -6 and indicated marginal and/or large instability in the troposphere (Fig. 3A). Soaring index had forecasted values of $35 \mathrm{~K}$ for the research area and indicates $80 \%$ risk of a thunderstorm. Estimated convective cloudiness for the observed period was $75 \%$ (Fig. 3B). KO index had forecasted values from -6 to -12 , that is, all values $\mathrm{KO} \leq 0$ indicate widespread thunderstorms 
and potentially instable atmosphere. Vertical motion in the observed area had forecasted values of -38 to $-46 \mathrm{hPa} \cdot \mathrm{h}^{-1}$, which indicated strong convective updrafts, particularly deep moist convection and cumuliform clouds with vertical development. (Fig. 3C).

As vertical motions were pronounced and there were conditions for deep convection, vorticity concentration of the rotating updraft along cyclonic wind shear axis enhanced the probability for the waterspout development. Strong SW upper-level flow (33-47 kn) brought warm and moist air and there was an area of positive relative vorticity $10-16\left(10^{\mathrm{E}-5} / \mathrm{S}\right)$ (Fig. 3D). This argument was confirmed by the fact that on the isobar height of $500 \mathrm{hPa}$ advection of absolute vorticity was positive and amounted to 0.03-0.05 (Fig. 3E).

Analysed SRH (storm relative helicity) wind factors had positive values for the research area of 250-300 $\mathrm{m}^{-2} \mathrm{~s}^{-2}(0-1 \mathrm{~km})$ and 400$600 \mathrm{~m}^{-2} \mathrm{~s}^{-2}(0-3 \mathrm{~km})$ (Fig. 3, F and G). These values indicated an increasing threat of tornadoes and supercells. Based on CAPE and SRH parameters, EHI index was estimated for the research area. The value of this index ranged from 3.1-7.5 and indicated a possibility of tornado events of various intensity according to F-scale. Negative (cold) advection of air temperature $\left(-15^{\circ} \mathrm{C}\right)$ was present at the height. AREG model (Fig. 3, H and I) shows high air temperature and high sea surface temperature (SST) of the Adriatic Sea in the vicinity of the Montenegro coast (around $25^{\circ} \mathrm{C}$ ), as well as temperature anomalies $\left(>1.3^{\circ} \mathrm{C}\right)$. This high air temperature was pushed by cold air inflow from upper-level atmosphere and cold frontal zone at the surface. Convergence line was formed at the surface on the sea and such mesoscale synoptic environment favoured convective initiation and intensification, that is, a waterspout development.

Based on synoptic material analysis, it can be said that mesoscale and synoptic conditions on all levels of the atmosphere (sea level, AT 850 hPa, AT 700 hPa, AT 500 hPa, AT $300 \mathrm{hPa}$ ) were favourable for waterspout formation and development. Such synoptic environment (instability energy in the atmosphere, as well as pronounced vertical movements, wind shear and a positive vorticity, extremely high relative air humidity-around $95 \%, \mathrm{~T}_{2 \mathrm{~m}}=25^{\circ} \mathrm{C}, \mathrm{T}_{850 \mathrm{hPa}}=10^{\circ} \mathrm{C}, \mathrm{T}_{500 \mathrm{hPa}}=-15^{\circ} \mathrm{C}$ ), created ideal conditions for a waterspout development. Warm and moist air was present at the surface and there was cold air in upper-level within the cut-off low. A local cyclonic field was formed at the surface. Dynamic conditions at $300 \mathrm{mb}$ indicate a positive divergence field and a jet streak. Therefore, thermodynamic conditions in synoptic scales formed ideal conditions for the waterspout event in Tivat on June 9, 2018 (around 01 UTC).

\section{Analysis of WRF-NMM model wind emagram and hodograph}

The WRF-NMM model (Janjic, 2003), which uses global model data as input parameters from Reading medium-term forecast (ECMWF), has been in operational use by the IHMSM. Based on WRF-NMM model, an emagram and hodograph for the Tivat airport were made with resolution of $0.5 \mathrm{~km}$ (00 UTC). The emagram shows increased vertical gradients of meteorological parameters-temperature decrease with height, increased relative humidity at the surface, sudden change of wind speed with height and wind shear (Fig. 4).

Vertical profile of the atmosphere for Tivat in the observed period indicates adiabatic instability from the lowest levels $(\mathrm{LCL}=540 \mathrm{~m})$, through the whole vertical profile, and up to the highest layers. Surface air temperature was $20.9^{\circ} \mathrm{C}$, while dew point temperature was over $17.5^{\circ} \mathrm{C}$. The zero isotherm height was $\mathrm{H}_{0}=3.6 \mathrm{~km}$, and the height of isotherm $\mathrm{H}_{-10}=5.3 \mathrm{~km}$. CIN (convective inhibition or negative CAPE) in the layer of maximum instability at $950 \mathrm{mb}$ was 1 (which is a weak cap by definition), while CAPE in this layer was $977 \mathrm{~J} / \mathrm{kg}$ (which is a positive CAPE by definition), so in this case there was a penetration of capping layer and lower PBL lifting in the region of positive CAPE, and thus favourable 


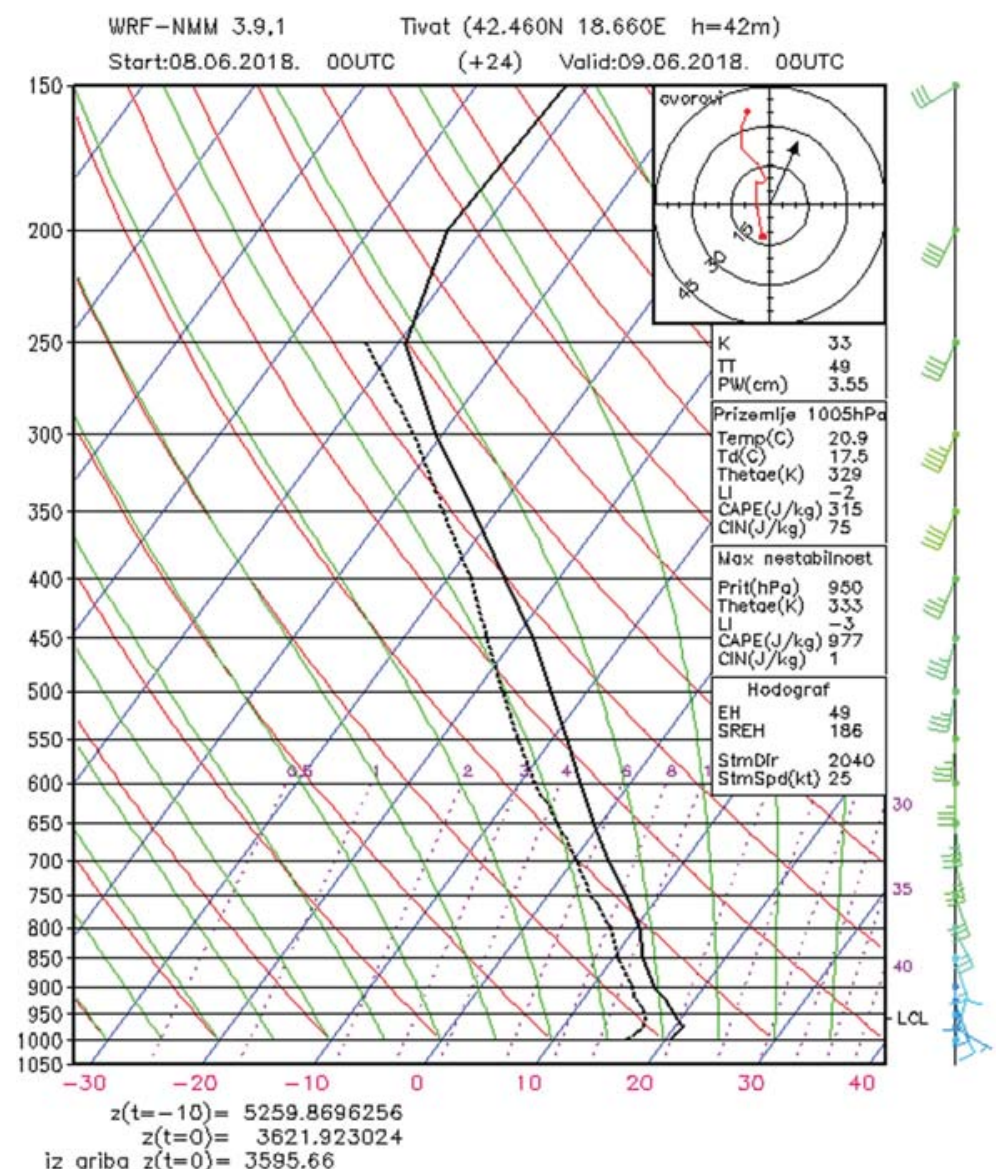

Figure 4. WRF-NMM model emagram and wind hodograph of $0.5 \mathrm{~km}$ resolution (00 UTC)

Source: Based on data from http://www.meteo.co.me/

conditions for a deep moist convection were created. The -3 value of $\mathrm{LI}$ in the layer of maximum instability of $950 \mathrm{mb}$ indicates marginal instability. Convective indices, as KI (33) and TT index (49), indicated a moderate convective potential and possible thunderstorms.

Hodograph (polar diagram in the upper right corner of the emagram) shows an increase of wind velocity with heightup to 35 knots at the 150 -mb layer, as well as wind shear in cumulonimbus at the level of $800-850 \mathrm{mb}$. The storm was moving at the speed of 25 knots, and the storm direction was $204^{\circ}$. Wind parameters indicating a rotation within the storm, EH $\left(49 \mathrm{~m}^{2} \mathrm{~s}^{-1}\right)$ and SREH $\left(186 \mathrm{~m}^{2} \mathrm{~s}^{-1}\right)$, suggested a possibility of a severe weather event.

\section{Analytic material analysis \\ SYNOP data}

In the previous part of this paper, the outputs of numerical models have been analysed. They were obtained one or two days before the waterspout event, which occurred in the early morning hours of 9 June, 2018. In order to confirm the forecast, the following part deals with analytical material based on SYNOP (surface synoptic observations), satellite and radar data. 
On June 9, 2018 (00-06 UTC), the surface and upper-level structure of the atmosphere over Europe was complex. Analytical maps of surface pressure, from 00 and 06 UTC (Fig. 5, A and B), show that in the north-eastern part of Europe there was an occluded front within a cyclone, moving slowly towards the east. A shallow depression with the centre over the Bay of Biscay was observed on the maps and its long occluded front was stretching over the central part of the Pyrenees, far to the west of the Mediterranean and northwest of Africa. A shallow cyclone was over the Balkans with the centre above the Mid Adriatic, and farther northward, above the Central Europe, there was a convergence line.

Higher resolution maps showed the cold front moving over the Southeast Europe (Fig. 5C), and at about 03 UTC the frontal line passed over the Bay of Kotor, exactly at the same moment of the waterspout formation. Until 06 UTC, the frontal system kept on moving towards the east, gradually weakening and the pressure began to rise on the west of it.

\section{Satellite data}

Various products of the second generation meteorological satellite (METEOSAT) have been used in the analysis: MSG-Airmass RGB, Dust RGB; WV6.2+Streamlines $(500 \mathrm{hPa} / 300 \mathrm{hPa})$. Satellite images (00 UTC) indicate convective cloudiness over most part of the Adriatic Sea and the southwestern and western part of Montenegro (the Bay of Kotor), which corresponds with the synoptic mesoscale situation of that day. The Figure $6 \mathrm{~A}$ in Airmass RGB colour combination indicates a convective cloudiness above the mid- Adriatic coast and the Bay of Kotor, its shifting and spreading towards the north
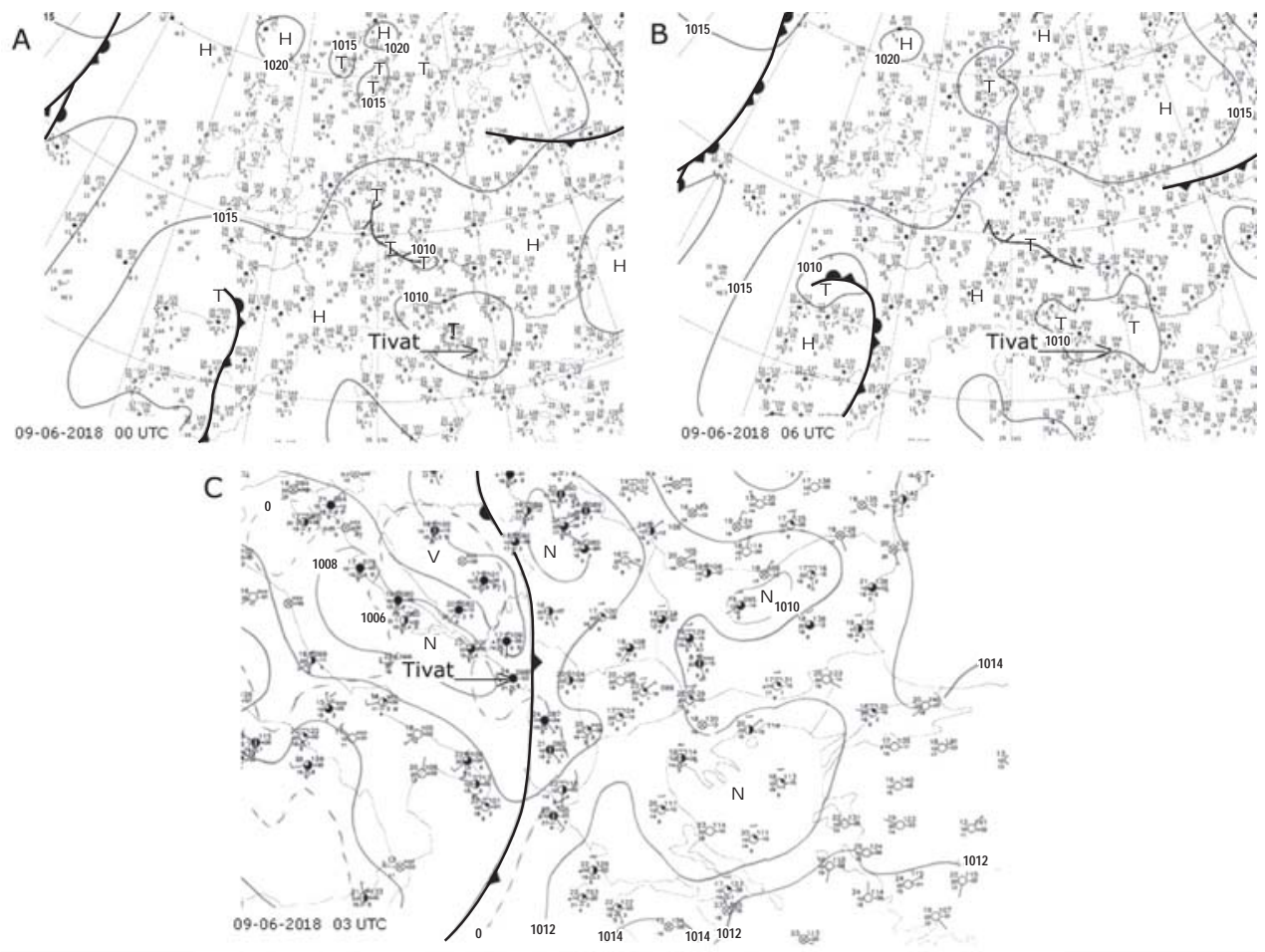

Figure 5. Surface synoptic map: over Europe at 00 UTC (A) and 06 UTC (B) and over the Balkan Peninsula at 03 UTC (C) on June 9, 2018

Source: Based on data from http://www1.wetter3.de/Archiv/ 

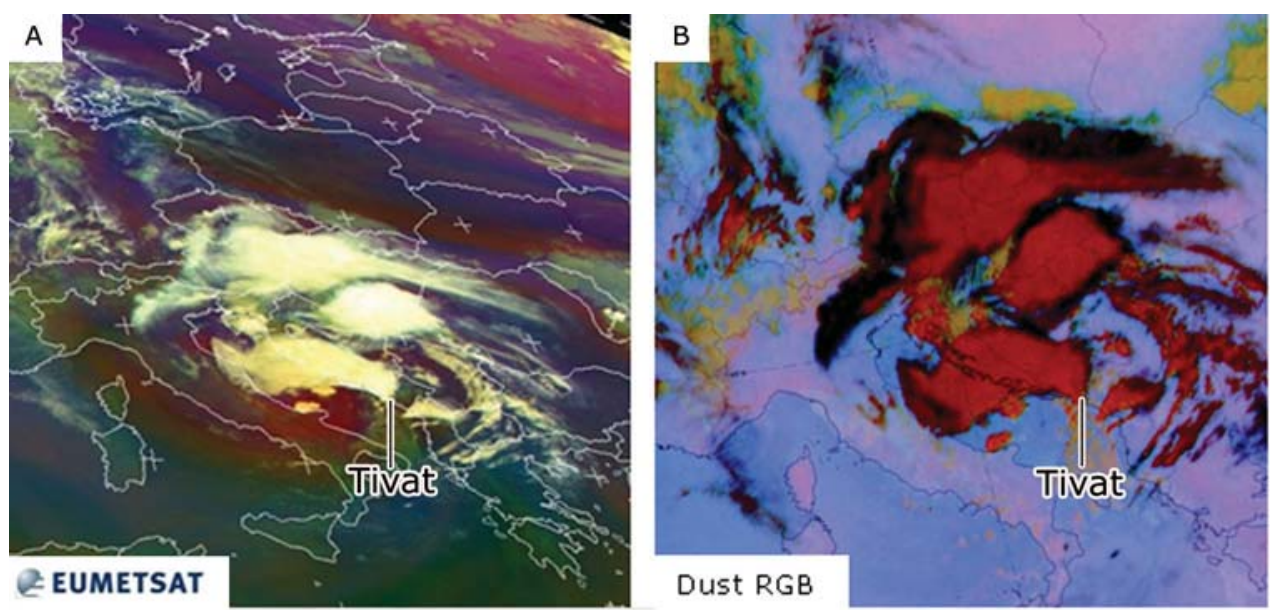

Meteosat Odeg Airmass, 2018-06-09 00:00:00 UTC
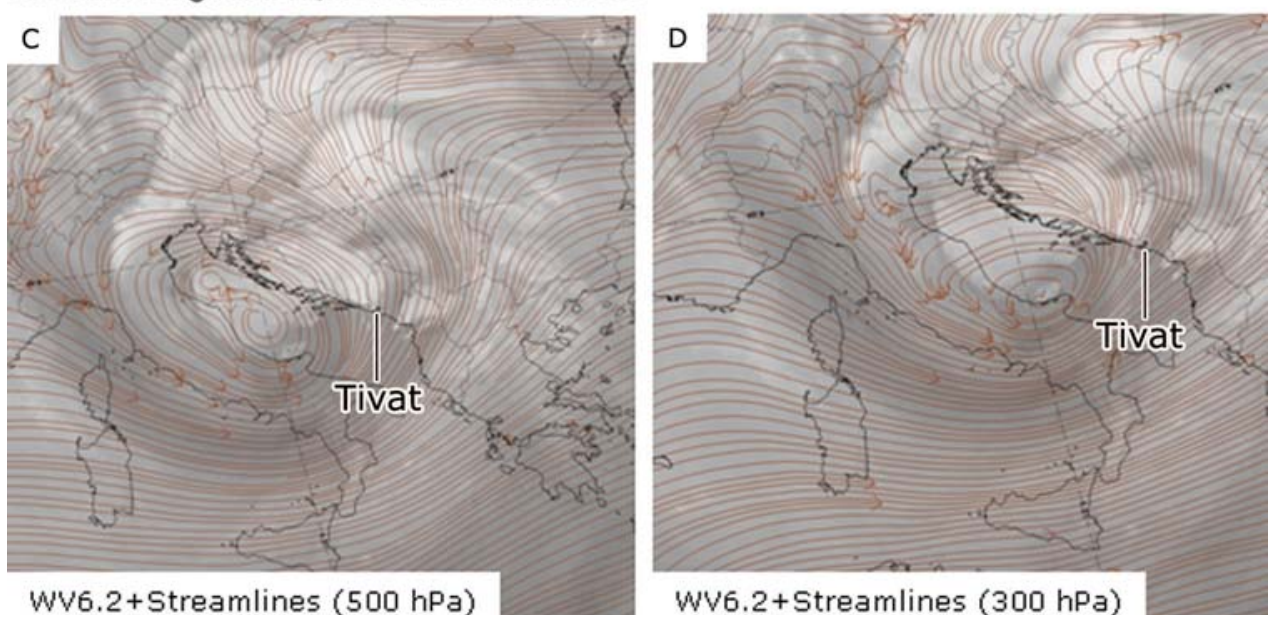

Figure 6. (A) Airmass RGB with corresponding cloudiness and atmospheric physics, (B) dust RGB, (C) WV6.2+Streamlines (500 hPa) and (D) WV6.2+Streamlines (300 hPa), at 00 UTC, June 9, 2018

Source: Based on data from http://www.meteo.co.me/ and http://eumetrain.org

under the influence of S-SW upper-air flow. Red shades on the image point to the presence of dry and warm air mass and descendant air movement. This process is connected with cyclogenesis. High advection of potential vorticity is present (jet streak) and it indicates an abrupt cyclogenesis. Green shades on the image indicate highly moist air mass in the upper troposphere and behind the convective cloudiness. White colour on the convective cell above the Bay of Kotor indicates high opaque clouds (a convective cell is recognized by the shape, not by the colour).
Dust RGB (Fig. 6B) points to high opaque clouds by its red shades ( $\mathrm{Cu}$ con, $\mathrm{TCu}, \mathrm{Cb}$ ) above the observed area. Dark blue and black colours on the image indicate the presence of high and thin cirrus clouds. WV6.2+Streamlines (500 hPa and $300 \mathrm{hPa}$ ) (Fig. 6, C and D) indicate an upper-air SW flow and the cyclogenesis process in the Adriatic.

\section{Radar data}

The violent process in the Bay of Kotor was recorded by the Gematronik type radar 

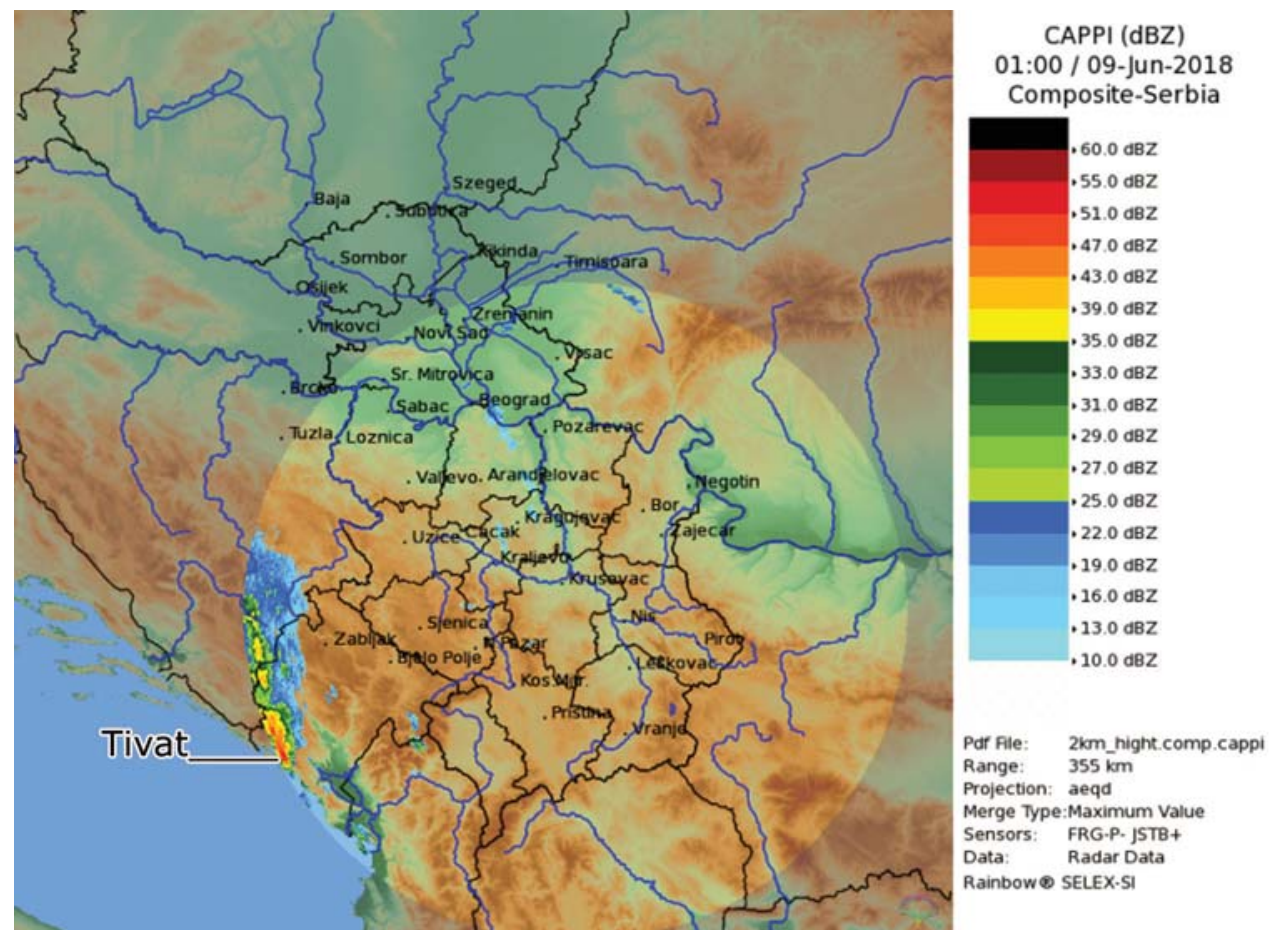

Figure 7. Composite radar image CAPPI (dBZ) $(10 \mathrm{~cm})$ at 01 UTC, June 9, 2018

Source: Based on data from http://www.hidmet.gov.rs

in the Jastrebac radar centre-Serbia (Fig. 7). The composite radar image clearly shows strong instability energy in that period (01 UTC). On the composite radar image CAPPI (dBZ) $(10 \mathrm{~cm})$, severe weather cloudiness was noticed moving over the Bay of Kotor, with the maximum reflectivity on the radar (50-55 dBZ). It has been estimated that the waterspout line was about 5-6 km long and it lasted 15-20 minutes. There were occasional rain, local short showers and a thunderstorm process till the middle of the day, but the process was most violent till 08 UTC.

Severe thunderstorm cloudiness, which spread over the Bay of Kotor, was moving northeast under the influence of S-SW upperair flow and between 00:27 UTC and 00:31 UTC (Fig. 8) passed over Tivat with maximum intensity on the radar. This corresponds to already presented synoptic situation and to main characteristics of isobaric relief at the surface and in the upper-level of atmosphere.
Horizontal and vertical cross-sections of the cloudiness (XSECT) have been done for the observed periods on the maximum reflectivity map ZMAX (3-10 cm), as well as on the map of severe meteorological events caused by this cloudiness $(3.2 \mathrm{~cm})$.

On the map of severe meteorological events $(3.2 \mathrm{~cm})$ at 00:27 UTC (Fig. 8A), small hail stones, $90 \%$ thunderstorm processes and heavy/moderate showers have been registered. Maximum reflectivity map (ZMAX) $(3-10 \mathrm{~cm})$ at 00:27 UTC (Fig. 8B) shows severe weather cloudiness in the area of the Bay of Kotor and Dubrovnik with maximum reflectivity of over $45 \mathrm{dBZ}$ (which is, according to the radar criteria, a condition for the hail formation). A vertical cross-section of the convective cell (XSECT) has been done on the map for the same period under the azimuth of $124^{\circ}$ in the 3.2 and $10 \mathrm{~cm}$ resolution (Fig. $8 \mathrm{C}$ ). Vertical cross-section reveal $\mathrm{Cb}$ cloud dimensions-cloud zone width of over $20 \mathrm{~km}$, while 


\section{METEOROLOGICAL EVENT}

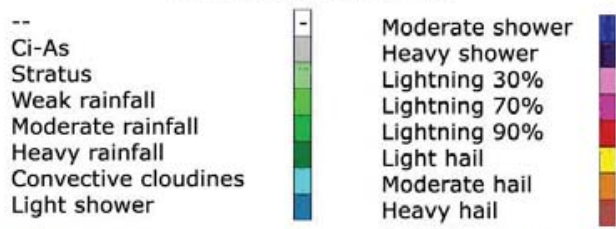
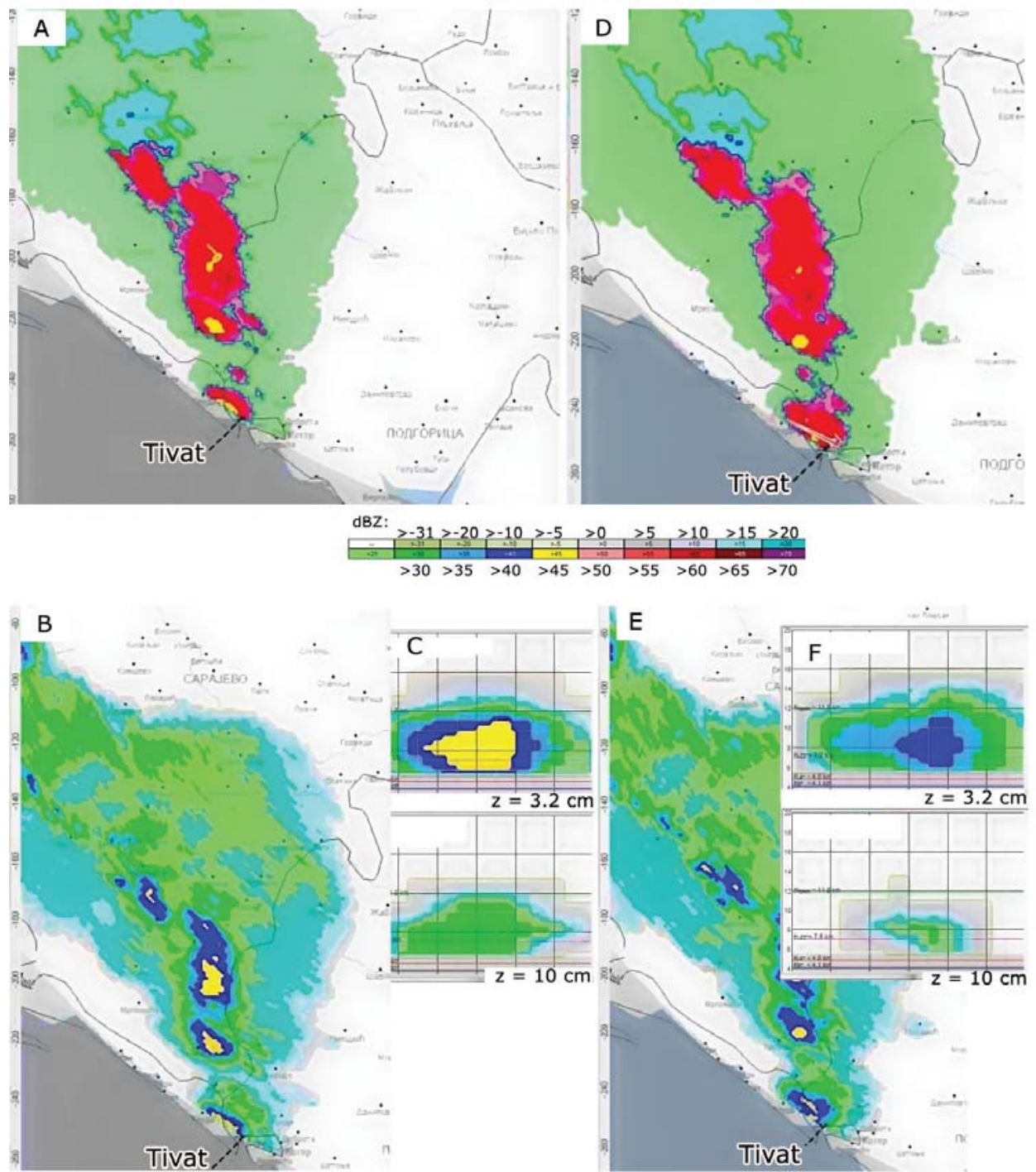

Figure 8. Map of severe meteorological events $(3.2 \mathrm{~cm})(A$ and $B)$ and maximum reflectivity map (ZMAX) $(3-10 \mathrm{~cm})(C$ and D) at 00:27 UTC (left) and 00:31 UTC (right). Inserted images (E and F): vertical crosssections of the selected cell XSECT) in the resolution of $3.2 \mathrm{~cm}$ (upper part) and $10 \mathrm{~cm}$ (lower part) under the azimuth of 1240 at 00:27 UTC (E) and 1180 at 00:31 UTC (F)

Source: Based on data from http://www.hidmet.gov.rs 
the height is around $16 \mathrm{~km}$ (the height of the tropopause was $11.8 \mathrm{~km}$, so the cloud lifted and penetrated the tropopause). Maximum reflectivity of the convective cell was over $45 \mathrm{dBZ}$. In the updraft zone a weakly marked WER was developed (surrounded with a stronger echo from above and aside), thus the rotation was not present. Weakly marked WER on the vertical cross-section indicates that there was not a supercell process whatsoever.

Moving farther in the NE direction and under the influence of a prevailing S-SW upperair flow, at 00:31 UTC, this convective cloudiness weakened, decreased in length and width as well as maximum reflectivity on the radar image, which indicated a gradual weakening of the convective process within it (Fig. 8, D and $\mathrm{E})$. The weakening of the process at 00:31 UTC can be noticed on Figure 8F.

\section{Discussion}

During the last two decades extreme weather events in Montenegro have been more frequently detected, such as extreme temperatures, heat waves, droughts and extreme precipitation (Buric et al., 2011; Buric et al., 2018; Buric et al., 2019; Burić \& Doderović, 2020; Doderović et al., 2020). This research paper had the aim of showing synoptic conditions which led to the waterspout development on the coast of Montenegro in the area of the Tivat airport on June 9, 2018, around 01 UTC. A detailed analysis of synoptic material, which was initialized one or two days before the event itself, has been done. That way, it has been shown that, thanks to numerical models which are getting more and more reliable, these and similar weather events could be forecasted in most cases.

According to the SYNOP data obtained from meteorological stations of IHMSM, from 00 UTC to 12 UTC, the total amount of precipitation was $70 \mathrm{~mm}$ on Cetinje, $50 \mathrm{~mm}$ on the airports in Tivat and Golubovci, $34 \mathrm{~mm}$ in Herceg Novi, $27 \mathrm{~mm}$ in Podgorica, $23 \mathrm{~mm}$ in Niksic, while other stations recorded less than $20 \mathrm{~mm}$ of rainfall (Fig. 9). From 01-03 UTC, cyclonic wind gusts of $28 \mathrm{~m} \cdot \mathrm{s}^{-1}$ or $101 \mathrm{~km} \cdot \mathrm{h}^{-1}$ were recorded in Herceg Novi. Anemometer located on the weather station in Tivat registered violent wind gusts of $18 \mathrm{~m} \cdot \mathrm{s}^{-1}$,

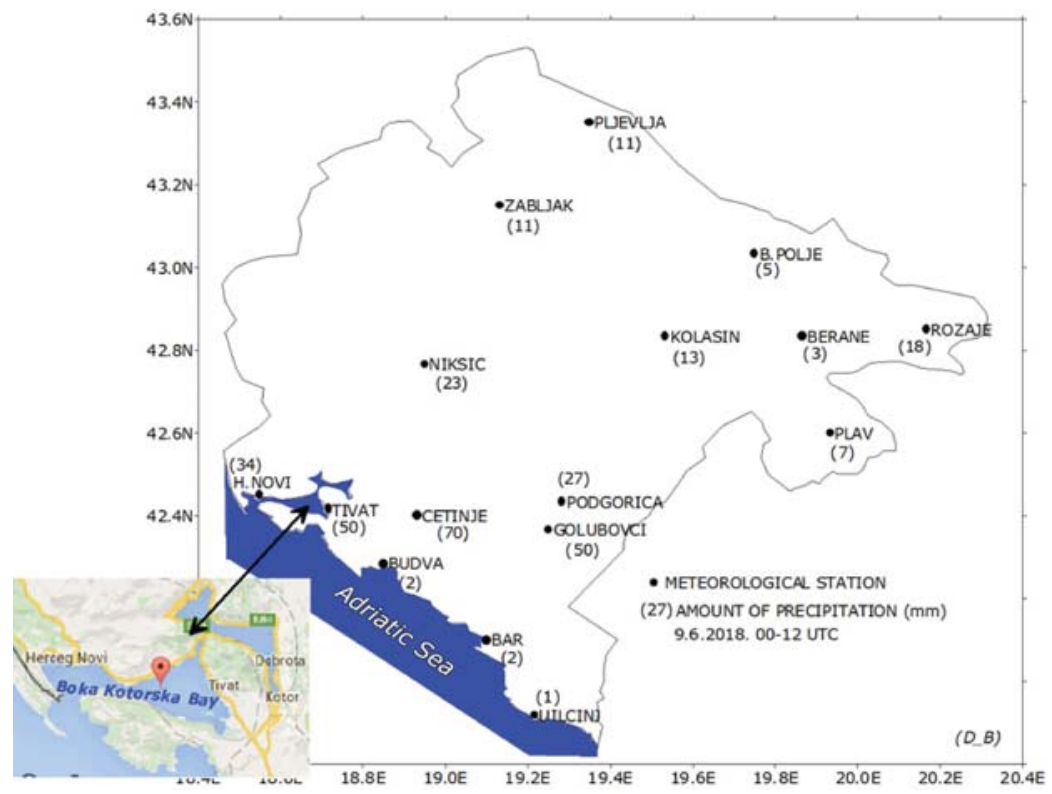

Figure 9. Amount of precipitation on weather stations in Montenegro on June 9, 2018 and the waterspout location in the Bay of Kotor 
but since it was a typical local event, it is almost certain that there were even more powerful wind gusts. The sea temperature along the Montenegro coastline was $25-26^{\circ} \mathrm{C}$.

Waterspout developing process is very complex. Mesoscale synoptic and thermodynamic conditions which favour the formation process of a waterspout include the presence of a gust front, convergence line and wind shear axis. High relative humidity of the air, high temperature of the sea surface and weak tropospheric winds are also needed so that a waterspout could develop (Hess \& Spillane, 1990; Golden \& Sabones, 1991; Simpson et al., 1991; Choy \& Sprat, 1994; Mihajlović et al., 2016). As an example, we can mention a waterspout outbreak over the Great Lakes in the USA, in 2003. When the cold arctic air, coming from the north of the American continent, flows over the warm waters of the Great Lakes, ideal mesoscale synoptic and thermodynamic conditions are formed for a waterspout development (Szilagyi, 2004; Mihajlović et al., 2016).

However, we should emphasize some facts which favour a waterspout development while talking about the Montenegro coast, and particularly the Bay of Kotor. The Montenegro coastline is a narrow region, with the width ranging from a few tens of meters to maximum $10 \mathrm{~km}$. Mountains rise up to $1900 \mathrm{~m}$ in the nearby hinterland. The Adriatic sea belongs to a group of warm seas, with the water temperature ranging from 24 to $28^{\circ} \mathrm{C}$ in the summer and at the beginning of the autumn. Optimal thermodynamic conditions for a waterspout development are high surface air temperatures and the presence of an air front passing over the warm Mediterranean and Adriatic waters and moving on towards the coastal Montenegro mountains. In both cases, there is a warm air uplift which causes the air to cool rapidly. When the air mass comes from the south into the Bay of Kotor, which is surrounded by mountain slopes, air currents are compacted and therefore the process of forced air updrafts is more turbulent. The air in the upper layers of troposphere should be very instable, humid and with enough latent energy. Such conditions favour the development of thunderstorm clouds- cumulonimbus $(\mathrm{Cb})$, but a so-called wind shear within the $\mathrm{Cb}$ is also necessary for a waterspout development.

Synoptic analysis (synoptic type has been identified), instability parameter analysis, radiosounding, satellite and radar analysis, as well as analysis of atmospheric instability have been carried out. The results of these analyses pointed out to thermal instability over a wide area of the Adriatic and the Bay of Kotor in the early morning hours on June 9, 2018, but also to favourable dynamic conditions at the surface and in the upper atmosphere.

Severe weather, followed by a formation of a vast cumulonimbus ( $\mathrm{Cb}$ ) cloud of high intensity, moved over Tivat and the Bay of Kotor with a maximum intensity on the radar in the period from 01:00 to 03:00 UTC, within the S-SW upper-air flow. A waterspout developed above the sea and soon swept over the land forming a relatively narrow and short path of $5-6 \mathrm{~km}$ in length. It lasted around 15-20 minutes in the coastal part and caused a real chaos. By applying the Fujita scale method and considering radar criteria, wind speed data obtained from meteorological stations and damage estimates, it can be concluded that the waterspout which swept over Tivat on June 9, 2018 belongs to the F0-F1 category on F-scale.

Based on methodology of synoptic type classification (Sioutas \& Keul, 2007; Sioutas, 2011) and thanks to a detailed analysis of the $500 \mathrm{mb}$ circulation, the position and characteristics of isobaric shapes in the upper levels, which are in relation to those at the surface, synoptic type for this situation can be determined as CLOSED (closed low) - SW (south-west flow). Over the Adriatic Sea, Italy, Croatia, Slovenia, Montenegro and Serbia there was an area of closed isobars which formed the so-called cut-off low at the height of $500 \mathrm{mb}$. Isolated low pressure centres and cyclonic vorticity fields were present at the surface. SW flow was formed and a frontal zone was noticed within these baric formations. 
According to the information obtained from the airport weather station in Tivat, late in the night - at 01 UTC on June 9, 2018, two aircrafts were taken by the vortex. Those were small business planes and one of them was rotated by 180 degrees, suffering minor damage. It was worse with the other plane since the waterspout literally lifted it up, turned and threw it to the aircraft parking platform (Fig. 10). The fact that the planes weighed more than $6 \mathrm{t}$ each speaks enough about the wind power. Nearby aircrafts, including much lighter helicopters which were out of range of the waterspout path, were not even moved by the storm. Along its narrow path, the waterspout damaged roofs of the houses, ripped up the trees, overturned big advertising billboards along the Adriatic Highway, but fortunately, without human losses.

\section{Conclusion}

Waterspouts and similar air vortices are exclusively of a local character. They mainly develop over the area having radius of 10 meters and they last only a few minutes, which makes it difficult to record them. Montenegro does not have a developed system for waterspouts observation and the national IHMSM does not have available data about waterspout and landspout frequency or intensity. There is a significant trend in temperature increase during the last 6-7 decades in Montenegro (Burić et al., 2019; Burić et al., 2020). Generally, higher temperature means energy surplus in the atmosphere which is released in the form of frequent extreme weather events. Based on available information, it is quite likely that the waterspout frequency has increased at the Adriatic Sea and along the Montenegro coast during the last 10 years. According to the detailed analysis of the waterspout which occurred in Tivat (Montenegrin coast) on June 9, 2018, sweeping over the town in the early morning hours (at about 03:00 CET, that is, 01:00 UTC), the main objective of this paper was to focus on these potentially dangerous weather events in the region of Montenegro and on necessity of tracking them so that they could be forecasted timely. In the context of global climate change, an early warning weather alert for

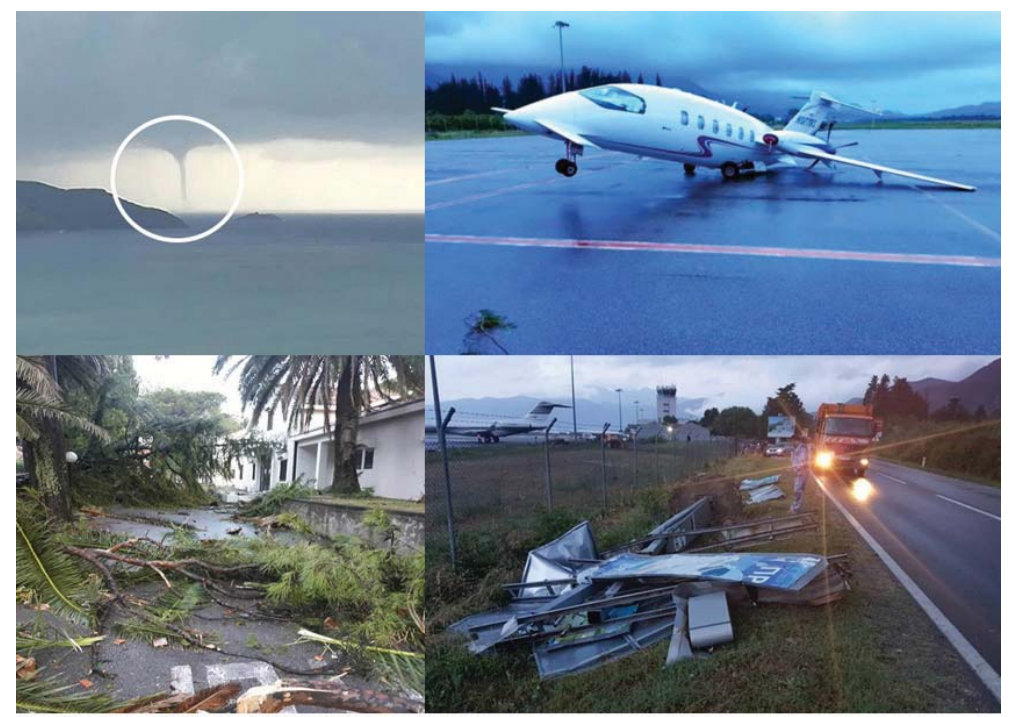

Figure 10. The waterspout in the Bay of Kotor (Tivat) and consequences of the storm in Tivat, June 9, 2018 Source: Retrieved from https://www.vijesti.me 
extreme weather events, such as a waterspout, has a great practical significance in saving human lives and in reducing negative consequences.

In this particular case (waterspout in Tivat), the general mesoscale synoptic situation was characterized by thermodynamic instability in lower and middle layers of the atmosphere: cold front passage over the warm water of the Adriatic as the main synoptic characteristic, pronounced directional and speed wind shear, as well as the presence of jet streak and pronounced horizontal field of positive divergence over the observed area. So, there was an advection of potential vorticity (PV) and PV conservation into lower layers of the troposphere, that is, a fast cyclogenesis and atmospheric instability.

This paper presents a contribution to the understanding of atmospheric conditions which create favourable synoptic and thermodynamic environment for a waterspout formation and development. The waterspout formation mechanism itself has been unknown until this very day, although there are some theoretical researches (e.g. Golden, 1971; Brady \& Szoke, 1988; Simpson et al., 1991; Choy \& Sprat, 1994; Wakimoto \& Lew, 1993; Renko et al., 2016). Based on a detailed research done in this paper, the authors suggest an application of the following synoptic tools while analysing waterspout events which belong to extraordinary and dangerous weather phenomena, that is, to weather hazards:

- initial analysis - various isobaric surfaces and other products of global and regional models have been analysed;
- sea surface temperature (SST) analysis of researched area (sea or ocean);

- synoptic types - application of the methodology suggested by Sioutas and Flocas (2003) and Sioutas (2011);

- radiosounding and wind hodograph analysis;

- thermodynamic instability parameters and wind parameters analysis;

- satellite and radar images analysis;

- application of Fujita scale (F-scale).

Apart from having educational and informational significance, this paper can help not only weather forecast experts, but also other people interested in the environment. Further investigation into meteorological environment, which favours waterspout formation at the Adriatic Sea and Mediterranean, is necessary in order to establish a more precise connection between presented thermodynamic parameters and mesoscale synoptic situation. Since such events belong to atmospheric hazards and present a danger to air and water traffic, as well as to human lives, a particular attention should be paid to this topic, not only in the region of the Mediterranean, but all over the world where such hazards occur.

\section{Acknowledgements:}

The authors thank IHMSM and RHMSS for the necessary data for this study (surface synoptic maps and radar images).

Editors' note:

Unless otherwise stated, the sources of tables and figures are the authors', on the basis of their own research.

\section{References}

Bissolli, P., Grieser, J., Dotzek, N., Welsch, M. (2007). Tornadoes in Germany 1950-2003 and their relation to particular weather conditions. Global and Planetary Change, 57(1-2), 124-138.

https://doi.org/10.1016/j.gloplacha.2006.11.007

Brady, R.H., Szoke, E.J. (1988). The landspout - A common type of Northeast Colorado tornado. In Preprints, 15th Conf. On Severe Local Storms (pp. 312-315). Baltimore, MD: American Meteorological Society. 
Browning, K.A. (1964). Airflow and precipitation trajectories within severe local storms which travel to the right of the winds. Journal of the Atmospheric Sciences, 21(6), 634-639.

https://doi.org/10.1175/1520-0469(1964)021<0634:AAPTWS>2.0.CO;2

Burić, D., Ducić, V., Luković, J. (2011). Kolebanje klime u Crnoj Gori u drugoj polovini XX i početkom XXI vijeka. Crnogorska Akademija Nauka i Umjetnosti.

Burić, D., Ducić, V., Mihajlović, J. (2013). The climate of Montenegro: Modificators and types - part two. Bulletin of the Serbian Geographical Society, 93(4), 83-102. https://doi.org/10.2298/GSGD1304083B

Burić, D., Ducić, V., Mihajlović, J. (2014). The climate of Montenegro: Modificators and types - part two. Bulletin of the Serbian Geographical Society, 94(1), 73-90. https://doi.org/10.2298/GSGD1401073B

Burić, D.B., Dragojlović, J.M., Milenković, M.Đ., Popović, Lj.Z., Doderović, M.M. (2018). Influence of variability of the East Atlantic Oscillation on the air temperature in Montenegro. Thermal Science, 22(1 Part B), 759-766. https://doi.org/10.2298/TSCl170710211B

Burić, D., Dragojlović, J., Penjišević-Sočanac, I., Luković, J., Doderović, M. (2019). Relationship between atmospheric circulation and temperature extremes in Montenegro in the period 1951-2010. In W. Leal Filho W, Trbic G, Filipovic, D. (Eds.), Climate change adaptation in Eastern Europe: Climate change management (pp. 29-42). Cham: Springer. https://doi.org/10.1007/978-3-030-03383-5_3

Burić, D., Doderović, M. (2020). Changes in temperature and precipitation in the instrumental period (1951-2018) and projections up to 2100 in Podgorica (Montenegro). International Journal of Climatology, 1-17. https://doi.org/10.1002/joc.6671

Doderović, M., Burić, D., Dragojlović, J. (2020). Significance of early announcement of weather extremes: Case study - Montenegro. EasyChair Preprint no. 3182. https://easychair.org/publications/preprint/Z42V

Choy, B.K., Spratt, S.M. (1994). A WSR-88D approach to waterspout forecasting. NOAA Tech Memo NWS SR, 156.

Davies, J.M. (1993). Hourly helicity, instability, and EHI in forecasting supercell tornadoes. In Preprints, 17th Conf on Severe Local Storms, St Louis, MO (pp. 107-111). American Meteorological Society.

Davies-Jones, R.P. (1984). Streamwise vorticity: The origin of updraft rotation in supercell storms. Journal of the Atmospheric Sciences, 41(20), 2991-3006.

https://doi.org/10.1175/1520-0469(1984)041<2991:SVTOOU>2.0.CO;2

Davies-Jones, R., Trapp, R.J., Bluestein, H.B. (2001). Tornadoes and tornadic storms. In Severe Convective Storms (pp. 167-222). Boston, MA: American Meteorological Society.

https://doi.org/10.1175/0065-9401-28.50.167

Dotzek, N. (2001). Tornadoes in Germany. Atmospheric Research, 56(1-4), 233-251. https://doi.org/10.1016/S0169-8095(00)00075-2

Dotzek, N. (2003). An updated estimate of tornado occurrence in Europe. Atmospheric Research, 67-68, 153-161. https://doi.org/10.1016/S0169-8095(03)00049-8

Ducić, V., Luković, J., Burić, D., Stanojević, G., Mustafić, S. (2012). Precipitation extremes in the wettest Mediterranean region (Krivošije) and associated atmospheric circulation types. Natural Hazards and Earth System Sciences, 12(3), 687-697. https://doi.org/10.5194/nhess-12-687-2012

Fujita, T.T. (1981). Tornadoes and downbursts in the context of generalized planetary scales. Journal of the Atmospheric Sciences, 38(8), 1511-1534. https://doi.org/10.1175/1520-0469(1981)038<1511:TADITC >2.0.CO;2

Galway, JG. (1956). The lifted index as a predictor of latent instability. Bulletin of the American Meteorological Society, 37(10), 528-529. https://doi.org/10.1175/1520-0477-37.10.528

Gianfreda, F., Miglietta, M.M., Sansò, P. (2005). Tornadoes in Southern Apulia (Italy). Natural Hazards, 34, 71-89. https://doi.org/10.1007/s11069-004-1966-3

Glickman, T.S. (2000). Glossary of Meteorology. 2nd Edition. Boston, MA: American Meteorological Society. 
Golden, J.H. (1971). Waterspouts and tornadoes over south Florida. Monthly Weather Review, 99(2), 146-154. https://doi.org/10.1175/1520-0493(1971)099<0146:WATOSF>2.3.CO;2

Golden, J.H. (1974). The life cycle of Florida Keys' waterspouts. I. Journal of Applied Meteorology and Climatology, 13(6), 676-692. https://doi.org/10.1175/1520-0450(1974)013<0676:TLCOFK>2.0.CO;2

Golden, J.H. (1977). An assessment of waterspout frequencies along the U.S. east and Gulf coasts. Journal of Applied Meteorology and Climatology, 16(3), 231-236. https://doi.org/10.1175/1520-0450(1977)016\%3C0231:AAOWFA\%3E2.0.CO;2

Golden, J.H., Sabones, M.E. (1991). Tornadic waterspout formation near interesting boundaries. In Preprints, 25th International Conference on Radar Meteorology. Preprints, 25th International Conference on Radar Meteorology (pp. 420-423). Paris: American Meteorological Society.

Guarnieri, A., Oddo, P., Pastore, M., Pinardi, N., Ravaioli, M. (2008). The Adriatic basin forecasting system: New model and system development. In H. Dahlin, M.J. Bell, N.C. Flemming, S.E. Petersson (Eds.), Coastal to global operational oceanography: Achievements and challenges (pp. 184190). Proceeding of the Fifth International Conference on EuroGOOS, 20-22 May 2008. Exeter, UK: EuroGOOS Publication. http://hdl.handle.net/2122/4782

Hagemeyer, B.H. (1994). First look at a marine supercell over the Gulf Stream. NOAA Tech Attach, SR/ SSD, 94-23, Ft Worth, TX.

Hess, G.D., Spillane, K.T. (1990). Waterspouts in the Gulf of Carpentaria. Australian Meteorological Magazine, 38, 173-179. http://www.bom.gov.au/jshess/docs/1990/hess1.pdf

Holzer, A.M. (2001). Tornado climatology of Austria. Atmospheric Research, 56(1-4), 203-211. https://doi.org/10.1016/S0169-8095(00)00073-9

Huschke, R.E. (Eds). (1959). Glossary of Meteorology. Boston, Mass: American Meteorological Society.

IPCC. 2014. Climate Change 2014: Synthesis Report. Contribution of Working Groups I, II and III to the Fifth Assessment Report of the Intergovernmental Panel on Climate Change [Core Writing Team, R.K. Pachauri and L.A. Meyer (eds.)]. Geneva, Switzerland: IPCC.

Janjic, Z.I., Gerrity Jr, J.P., Nickovic, S. (2001). An alternative approach to nonhydrostatic modeling. Monthly Weather Review, 129(5), 1164-1178. https://doi.org/10.1175/1520-0493(2001)129<1164:AAATNM>2.0.CO;2

Janjic, Z.I. (2003). A nonhydrostatic model based on a new approach. Meteorology and Atmospheric Physics, 82, 271-285. https://doi.org/10.1007/s00703-001-0587-6

Kunz, M. (2007). The skill of convective parameters and indices to predict isolated and severe thunderstorms. Natural Hazards and Earth System Sciences, 7(2), 327-342. https://doi.org/10.5194/nhess-7-327-2007

Kurnik, B., Füssel, H.M., van der Linden, P., Simmons, A. (2017). Changes in the climate system, Section 3.2: Atmosphere. In Climate change, impacts and vulnerability in Europe 2016: An indicator-based report (pp 69-88). EEA report, No 1/2017. https://www.eea.europa.eu/publications/climate-changeimpacts-and-vulnerability-2016

Matsangouras, I., Nastos, P., Bluestein, H., Pytharoulis, I., Papachristopoulou, K., Miglietta, M. (2017). Analysis of waterspout environmental conditions and of parent-storm behaviour based on satellite data over the southern aegean sea of greece. International Journal of Climatology, 37(2), 1022-1039. https://doi.org/10.1002/joc.4757

Mihajlović, J., Ducić, V., Burić, D. (2016). Tornadic waterspout event in Split (Croatia) - analysis of meteorological environment. Journal of the Geographical Institute Jovan Cvijić, SASA, 66(2), 185-202. https://doi.org/10.2298/IJGI1602185M

Miller, R.C. (1967). Notes on analysis and severe storm forecasting procedures of the Air Force Global Weather Central. Technical Report 200 (Rev). Air Weather Service, Scott Air Force Base.

Moncrieff, M.W., Miller, M.J. (1976). The dynamics and simulation of tropical cumulonimbus and squall lines. Quarterly Journal of the Royal Meteorological Society, 102(432), 373-394.

https://doi.org/10.1002/qj.49710243208 
Mostafa, A.N., Wheida, A., El Nazer, M., Adel, M., El Leithy, L., Siour, G., ... Alfaro, S.C. (2019). Past (1950-2017) and future (-2100) temperature and precipitation trends in Egypt. Weather and Climate Extremes, 26, 100225. https://doi.org/10.1016/j.wace.2019.100225

Oddo, P., Pinardi, H., Zavatarelli, M. (2005). A numerical study of the interannual variability of the Adriatic Sea (2000-2002). Science of The Total Environment, 353(1-3), 39-56. https://doi.org/10.1016/j.scitotenv.2005.09.061

Oddo, P., Pinardi, H., Zavatarelli, M., Colucelli, A. (2006). The Adriatic basin forecasting system. Acta Adriatica: International Journal of Marine Sciences, 47(Suppl), 169-184. https://hrcak.srce.hr/8550

Palmieri, S., Pulcini, A. (1979). Trombe d'aria sull'Italia. Rivista di Meteorologia Aeronautica, 39(3-4), 263-277.

Penzar, B., Penzar, I., Orlić, M. (2001). Vrijeme i klima hrvatskog Jadrana. Zagreb-Koprivnica-Split: Dr. Feletar, Hrvatski hidrografski institut.

Peterson, R.E. (1998). A historical review of tornadoes in Italy. Journal of Wind Engineering and Industrial Aerodynamics, 74-76, 123-130. https://doi.org/10.1016/S0167-6105(98)00010-5

Pipinato, A. (2018). Recent northeast Italian tornado events: lesson learned for improving structures. Natural Hazards, pp 40. https://doi.org/10.1007/s11069-018-3380-2

Powers, J.G., Klemp, J.B., Skamarock, W.C., Davis, C.A., Dudhia, J., Gill, D.O., ... Duda, M.G. (2017). The weather research and forecasting model: Overview, system efforts, and future directions. Bulletin of the American Meteorological Society, 98(8), 1717-1737. https://doi.org/10.1175/BAMS-D-15-00308.1

Radović, V., Iglesias, I. (2020). Extreme weather events: Definition, classification, and guidelines towards vulnerability reduction and adaptation management. In W. Leal Filho, A.M. Azul, L. Brandli, P.G. Özuyar, T. Wall (Eds.), Climate Action. Cham: Springer. https://doi.org/10.1007/978-3-319-95885-9_68

Renko, T., Kuzmić, J., Šoljan, V., Strelec Mahović, N. (2016). Waterspouts in the Eastern Adriatic from 2001 to 2013. Natural Hazards, 82, 441-470. https://doi.org/10.1007/s11069-016-2192-5

Rossow, V.J. (1970). Observations of waterspouts and their parent clouds. Washington: National Aeronautics and Space Administration. https://ntrs.nasa.gov/archive/nasa/casi.ntrs.nasa.gov/19700020540.pdf

Snow, J. (2020). Tornado. In Encyclopædia Britannica. Retrieved from https://www.britannica.com/science/tornado

Simpson, J., Roff, G., Morton, B.R., Labas, K., McCumber, M., Penc, R. (1991). A Great Salt Lake waterspout. Monthly Weather Review, 119(12), 2741-2770. https://doi.org/10.1175/1520-0493-119-12-2740.1

Sioutas, M.V. (2011). A tornado and waterspout climatology for Greece. Atmospheric Research, 100(4), 344-356. https://doi.org/10.1016/j.atmosres.2010.08.011

Sioutas, M.V., Keul, A.G. (2007). Waterspouts of the Adriatic, Ionian and Aegean Sea and their meteorological environment. Atmospheric Research, 83(2-4), 542-557.

https://doi.org/10.1016/j.atmosres.2005.08.009

Skamarock, W.C., Klemp, J.B., Dudhia, J., Gill, D.O., Barker, D., Duda, M.G., ... Powers, J.G. (2008). A description of the advanced research WRF Version 3. (No. NCAR/Tech. Note - 475+STR). University Corporation for Atmospheric Research. http://dx.doi.org/10.5065/D68S4MVH

Sioutas, M., Flocas, H.A. (2003). Hailstorms in Northern Greece: synoptic patterns and thermodynamic environment. Theoretical and Applied Climatology, 75, 189-202. https://doi.org/10.1007/s00704-003-0734-8

Spinoni, J., Szalai, S., Szentimrey, T., Lakatos, M., Bihari, Z., Nagy, A., ... Vogt, J. (2014). Climate of the Carpathian Region in the period 1961-2010: Climatologies and trends of 10 variables. International Journal of Climatology, 35, 1322-1341. https://doi.org/10.1002/joc.4059

Stadtherr, L., Coumou, D., Petoukhov, V., Petri, S., Rahmstorf, S. (2016). Record Balkan floods of 2014 linked to planetary wave resonance. Science Advences. 2(4), e1501428.

https://doi.org/10.1126/sciadv.1501428 
Stagge, J.H., Kingston, D.G., Tallaksen, L.M., Hannah, D.M. (2017). Observed drought indices show increasing divergence across Europe. Scientific Reports, 7, 14045. https://doi.org/10.1038/s41598-017-14283-2

Szilagyi, W. (2004). The great waterspout outbreak of 2003. Mariners Weather Log, 48 (3). Retrieved from https://www.vos.noaa.gov/MWL/dec_04/waterspout.shtml

Wakimoto, R.M., Lew, J.K. (1993). Observations of a Florida waterspout during Cape. Weather and Forecasting, 8(4), 412-423. https://doi.org/10.1175/1520-0434(1993)008<0412:OOAFWD>2.0.CO;2

World Meteorological Organization (WMO). (2016). Guidelines on the definition and monitoring of extreme weather and climate events: Draft version - first review by TT-DEWCE (Dec 2015). [May 11, 2020] http://www.wmo.int/pages/prog/wcp/ccl/opace/opace2/documents/DraftversionoftheGuidelin esontheDefinitionandMonitoringofExtremeWeatherandClimateEvents.pdf

Zanini, M.A., Hofer, L., Faleschini, F., Pellegrino, C. (2017). Building damage assessment after the Riviera del Brenta tornado, northeast Italy. Natural Hazards, 86(3), 1247-1273.

https://doi.org/10.1007/s11069-017-2741-6 